\title{
Egg consumption and risk of coronary heart disease and stroke: dose-response meta-analysis of prospective cohort studies
}

\author{
(c) $(1)$ (1) OPEN ACCESS
}

\author{
Ying Rong doctoral student ${ }^{12}$, Li Chen research fellow ${ }^{12}$, Tingting Zhu research fellow ${ }^{12}$, Yadong \\ Song research fellow ${ }^{12}$, Miao Yu research fellow ${ }^{12}$, Zhilei Shan research fellow ${ }^{12}$, Amanda Sands \\ doctoral student ${ }^{3}$, Frank B Hu professor ${ }^{3}$, Liegang Liu professor ${ }^{12}$
}

${ }^{1}$ Department of Nutrition and Food Hygiene, Hubei Key Laboratory of Food Nutrition and Safety, Tongji Medical College, Huazhong University of Science and Technology, 430030 Wuhan, People's Republic of China; ${ }^{2}$ Ministry of Education Key Lab of Environment and Health, School of Public Health, Tongji Medical College, People's Republic of China; ${ }^{3}$ Departments of Nutrition and Epidemiology, Harvard School of Public Health, Boston, MA, USA

\begin{abstract}
Objective To investigate and quantify the potential dose-response association between egg consumption and risk of coronary heart disease and stroke.

Design Dose-response meta-analysis of prospective cohort studies.

Data sources PubMed and Embase prior to June 2012 and references of relevant original papers and review articles.

Eligibility criteria for selecting studies Prospective cohort studies with relative risks and $95 \%$ confidence intervals of coronary heart disease or stroke for three or more categories of egg consumption.

Results Eight articles with 17 reports (nine for coronary heart disease, eight for stroke) were eligible for inclusion in the meta-analysis (3 081 269 person years and 5847 incident cases for coronary heart disease, and 4148095 person years and 7579 incident cases for stroke). No evidence of a curve linear association was seen between egg consumption and risk of coronary heart disease or stroke $(P=0.67$ and $\mathrm{P}=0.27$ for non-linearity, respectively). The summary relative risk of coronary heart disease for an increase of one egg consumed per day was 0.99 (95\% confidence interval 0.85 to $1.15 ; P=0.88$ for linear trend) without heterogeneity among studies $\left(P=0.97, I^{2}=0 \%\right)$. For stroke, the combined relative risk for an increase of one egg consumed per day was 0.91 ( 0.81 to $1.02 ; P=0.10$ for linear trend) without heterogeneity among studies $\left(P=0.46, I^{2}=0 \%\right)$. In a subgroup analysis of diabetic populations, the relative risk of coronary heart disease comparing the highest with the lowest egg consumption was 1.54 (1.14 to $2.09 ; P=0.01$ ). In addition, people with higher egg consumption had a $25 \%(0.57$ to $0.99 ; \mathrm{P}=0.04)$ lower risk of developing hemorrhagic stroke.
\end{abstract}

Conclusions Higher consumption of eggs (up to one egg per day) is not associated with increased risk of coronary heart disease or stroke. The increased risk of coronary heart disease among diabetic patients and reduced risk of hemorrhagic stroke associated with higher egg consumption in subgroup analyses warrant further studies.

\section{Introduction}

Cardiovascular disease is now a public health crisis, affecting millions of people in both developed and developing countries. Although the rate of death attributable to the disease has declined in developed countries in the past several decades, it is still the leading cause of death and extorts a heavy social and economic toll globally. ${ }^{1-3}$ In low and middle income countries, the prevalence of cardiovascular disease has increased dramatically. By 2020, the disease is forecasted to be the major cause of morbidity and mortality in most developing nations. ${ }^{4}$

In recent decades, concern has mounted regarding the high prevalence and costs associated with cardiovascular disease, with growing interest in altering risk factors and reversing this global epidemic. Among the known risk factors for cardiovascular disease, levels of low density lipoprotein (LDL) cholesterol have aroused particular attention. In the Women's Health Study, after a mean follow-up of eight years, participants with the highest levels of LDL cholesterol showed a notably higher risk of cardiovascular events than those with the lowest levels. ${ }^{5}$ In addition, several meta-analyses of observational studies and randomized controlled trials have found that a reduction in concentrations of LDL cholesterol could significantly reduce the risk of coronary heart disease and stroke 
incidence and mortality.$^{6-9}$ Diet is an important determinant of serum cholesterol, but dietary cholesterol has only a modest contribution to plasma concentrations of LDL cholesterol. ${ }^{10} \mathrm{On}$ the other hand, dietary cholesterol may prompt the oxidation of LDL and increase postprandial lipemia, which could raise the risk of vascular disease. ${ }^{11}$ To minimize the elevation of blood cholesterol and reduce the risk of cardiovascular disease, the American Heart Association (AHA) has recommended the public to consume less than $300 \mathrm{mg} /$ day of cholesterol. ${ }^{12}{ }^{13}$

Since eggs are a major source of dietary cholesterol, with one large egg containing almost $210 \mathrm{mg}$ of cholesterol, the public has been recommended to limit egg consumption unless the intake of other foods high in cholesterol is restricted. ${ }^{14}$ However, eggs are also an inexpensive and low calorie source of many other nutrients, including minerals, proteins, and unsaturated fatty acids, which could lower the risk of cardiovascular disease.$^{15}$ Additionally, in populations following a carbohydrate restricted diet, dietary cholesterol from eggs could increase plasma concentrations of high density lipoprotein (HDL) cholesterol ${ }^{16}$ which has been suggested to protect against vascular disease. ${ }^{17}{ }^{18}$ Therefore, some organizations have recommended that reducing egg intake might not be important for healthy people with normal levels of cholesterol in the blood. ${ }^{19}$ Food based dietary guidelines from countries including Nepal, Thailand, and South Africa recommend consuming eggs every day or regularly as part of a healthy diet. ${ }^{20}$

Several prospective cohort studies have examined the association between egg consumption and risk of coronary heart disease and stroke. However, the relation between egg consumption and risk of cardiovascular disease remains controversial. Therefore, we conducted a dose-response meta-analysis of prospective cohort studies to quantify the association between egg consumption and risk of coronary heart disease and stroke.

\section{Methods}

\section{Search strategy}

We conducted a literature search of PubMed (Medline) and Embase from January 1966 through June 2012 for prospective cohort studies examining the association between egg consumption and risk of CHD and stroke. PubMed search terms were "Cardiovascular Diseases" [MeSH] or "Stroke" $[\mathrm{MeSH}]$ or "Coronary Disease" [MeSH] or "myocardial infarction" [MeSH] or CHD) and egg. Similar search terms were used for Embase. In addition, we scrutinized references from relevant original papers and review articles to identify further pertinent studies. No language restrictions were imposed. We followed the standard criteria for conducting meta-analyses of observational studies and reporting the results. ${ }^{21}$

\section{Study selection}

Studies were included in this meta-analysis if they satisfied the following criteria: the study design was prospective, the exposure of interest was egg consumption, the outcome was coronary heart disease or stroke, and the investigators reported relative risks with $95 \%$ confidence intervals for at least three quantitative categories of egg intake. Additionally, we excluded reviews, editorials, non-human studies, and letters without sufficient data. Studies of other exposures and diseases were also excluded. If study populations were reported more than once, we used the result with the longest follow-up time.

\section{Data extraction}

Data extraction was carried out independently by two authors (YR and LC) using a standard extraction form. We extracted the following information from each study: authors, year of publication, study name, study location, years of follow-up, sample size (number of participants and incident cases), participants' characteristics (age and sex), endpoints (coronary heart disease, stroke, or both), outcomes ascertainment, egg consumption categories, covariates adjusted in the multivariable analysis, and relative risks (95\% confidence intervals) for all categories of egg consumption.

Quality assessment was performed according to the Newcastle-Ottawa quality assessment scale, ${ }^{22}$ which is a validated scale for non-randomised studies in meta-analyses. This scale awards a maximum of nine points to each study: four for selection of participants and measurement of exposure, two for comparability of cohorts on the basis of the design or analysis, and three for assessment of outcomes and adequacy of follow-up. We assigned scores of 0-3, 3.5-6, and 6.5-9 for low, moderate, and high quality of studies, respectively. When studies had several adjustment models, we extracted those that reflected the maximum extent of adjustment for potentially confounding variables.

For studies that reported egg intake as servings per week or day, we assumed that each serving was equivalent to one egg. For studies that lacked the unit of consumption, the categories were estimated by multiplying the frequency of consumption from the food frequency questionnaires with an average portion size according to the mean intake derived from the $24 \mathrm{~h}$ diaries. We contacted the authors if the data of interest were not directly shown in the publications. To resolve discrepancies, we used group consensus and consulted a third reviewer.

\section{Statistical analysis}

In this meta-analysis, the relative risks and $95 \%$ confidence intervals were considered as the effect size for all studies, and the hazard ratios were deemed equivalent to relative risks. Any results stratified by sex were treated as two separate reports. Those articles reporting both coronary heart disease and stroke were also treated as two separate reports. Owing to the distinct cut-off points for categories in different articles, we computed a relative risk with $95 \%$ confidence interval for an increased intake of one egg per day for each report. The method described by Greenland and Longnecker ${ }^{23}$ and Orsini and colleagues ${ }^{24}$ was used to calculate the trend from the correlated estimates for $\log$ relative risk across categories of egg consumption. The amount of egg consumption, distributions of cases and person years, and relative risks and $95 \%$ confidence intervals were extracted according to this method.

The median or mean egg consumption in each category was used as the corresponding dose of consumption. The midpoint of the upper and lower boundaries was considered the dose of each category if the median or mean intake per category was not available. If the highest category was open ended, the midpoint of the category was set at 1.5 times the lower boundary. If the number of cases and person years were not available, we used the relative risks comparing the highest versus lowest categories of egg intake to obtain a summary estimate.

In addition, we evaluated a potential curve linear association between egg consumption and risk of coronary heart disease and stroke, using restricted cubic splines with three knots at percentiles $10 \%, 50 \%$, and $90 \%$ of the distribution. ${ }^{25} \mathrm{~A} \mathrm{P}$ value for curve linearity or non-linearity was calculated by testing the 
null hypothesis that the coefficient of the second spline is equal to zero.

The heterogeneity among studies was estimated by the Cochran $\mathrm{Q}$ test and $\mathrm{I}^{2}$ statistic. ${ }^{26}$ Heterogeneity was confirmed with a significance level of $\mathrm{P} \leq 0.10$. The $\mathrm{I}^{2}$ statistic describes the percentage of total variation in point estimates that can be attributed to heterogeneity. For the $\mathrm{I}^{2}$ metric, we considered low, moderate, and high $\mathrm{I}^{2}$ values to be $25 \%, 50 \%$, and $75 \%$, respectively. ${ }^{26}$ We used a fixed effect model (Mantel-Haenszel method) when heterogeneity was negligible, and a random effect model (DerSimonian and Laird method) when heterogeneity was significant. ${ }^{28}$ Forest plots and funnel plots were used to examine the overall effect and assess the publication bias, respectively.

We also conducted analyses stratified by sex, study location, number of cases and participants, duration of follow-up, repeated egg consumption measurements, study quality, and whether diet variables or cholesterol levels were controlled for in models. All statistical analyses were performed with Stata version 11 (Stata Corp), and all tests were two sided with a significance level of 0.05 .

\section{Results}

\section{Literature search}

Figure $1 \Downarrow$ shows the results of literature research and selection. We identified 616 articles from PubMed and 824 articles from Embase prior to 20 June 2012. After exclusion of duplicates and studies that did not fulfill the inclusion criteria, 16 remaining articles seemed to be relevant for this meta-analysis. After evaluating the full texts of these 16 publications, we excluded eight articles as follows. Two articles ${ }^{29}{ }^{30}$ were excluded owing to lack of sufficient data for estimation of relative risks. Another two articles ${ }^{31} 32$ were excluded because they did not separately report the relative risks and $95 \%$ confidence intervals for coronary heart disease or stroke. We also excluded one report ${ }^{33}$ because it was the meeting abstract of the study by Scrafford and colleagues. ${ }^{34}$ A study by He and colleagues ${ }^{35}$ was excluded because it reported the intermediate follow-up results of Health Professionals Follow-up Study. The final meta-analysis included eight articles, of which four ${ }^{34}$ 36-38 examined men and women separately. For the study by Scrafford and colleagues, ${ }^{34}$ the estimate of the association between egg consumption and stroke mortality among men was imprecise because of sparse data, and thus for this report we included only data for women. In total, our meta-analysis included eight articles with 17 independent reports.

\section{Study characteristics}

Tables $1 \Downarrow$ and $2 \Downarrow$ show the information extracted from the included studies, all of which had prospective cohort designs and participants with no prior diagnoses of cardiovascular disease at baseline. The meta-analysis consisted of 263938 participants with 3081269 person years of follow-up for coronary heart disease, and 210404 patients with 4148095 person years of follow-up for stroke. Among the participants, we documented 5847 cases of coronary heart disease during follow-up periods ranging from eight to 20 years, and 7579 cases of stroke during a follow-up ranging from 8.8 to 22 years. Three cohorts ${ }^{37} 3940$ were among Asians (Japan), and the others $^{34} 36384142$ were conducted in the United States. Egg consumption was measured by food frequency questionnaires in all studies. Four studies ${ }^{3638} 4042$ used repeated measurements to update dietary information to more accurately reflect the dietary intakes over follow-up. Results of study quality assessment (score 0-9) yielded a score of 6.5 or above (high quality) for all studies, with an average score of 7.6 (web appendix, tables A and B).

\section{Association between egg consumption and risk of coronary heart disease}

Six articles ${ }^{34} 367^{30-42}$ with nine reports were included in the dose-response analysis of egg consumption and risk of coronary heart disease. Using a restricted cubic splines model, we found no evidence of a curve linear association between egg consumption and risk of coronary heart disease $(\mathrm{P}=0.67$ for non-linearity; fig $2 \Downarrow$ ). The summary relative risk of coronary heart disease for an increase of one egg per day was 0.99 (95\% confidence interval 0.85 to $1.15 ; \mathrm{P}=0.88$ for linear trend). We saw no heterogeneity among studies $\left(\mathrm{P}=0.97, \mathrm{I}^{2}=0 \%\right.$; fig $\left.3 \Downarrow\right)$. Additionally, Begg and Egger regression tests provided no evidence of substantial publication bias ( $\mathrm{P}>0.05$ for both tests). Among the included studies, two articles ${ }^{34} 37$ (four total reports) examined the relation between egg consumption and risk of coronary heart disease in populations with diabetes. Owing to the lack of data for person years in diabetic populations, we obtained the summary relative risk comparing the highest with the lowest egg consumption for coronary heart disease in diabetic patients (relative risk 1.54 (1.14 to 2.09); $\mathrm{P}=0.01$; table $3 \Downarrow$; web appendix, table C).

\section{Association between egg consumption and risk of stroke}

This dose-response analysis involved six articles ${ }^{34}$ 37-39 4142 with eight reports on egg consumption and stroke risk. We did not find a curve linear association between egg consumption and risk of stroke ( $\mathrm{P}=0.27$ for non-linearity; fig $4 \Downarrow)$. The combined relative risk of stroke for an increment of one egg consumed per day was 0.91 (95\% confidence interval 0.81 to $1.02 ; \mathrm{P}=0.10$ for linear trend; fig $5 \Downarrow$ ). No heterogeneity of effect estimates on relative risks was observed $\left(\mathrm{P}=0.46, \mathrm{I}^{2}=0 \%\right)$. Neither the Begg test nor the Egger test for publication bias reached significance ( $\mathrm{P}>0.05$ for both tests). In addition, three articles $^{3437}$ with four reports provided information on fatal stroke (pooled relative risk 0.94 (0.80 to 1.10$)$; $\mathrm{P}=0.46$; table 3). Moreover, four articles 38394142 reported results for different types of stroke, and three articles ${ }^{3441} 42$ provided results for stroke in those with diabetes. For these studies, the combined relative risks comparing the highest versus lowest egg intake were 0.75 (0.57 to 0.99) for hemorrhagic stroke, 0.91 (0.82 to 1.01) for ischemic stroke, and 0.80 (0.29 to 2.15$)$ for total stroke among people with diabetes (table 3 ; web appendix, table D).

\section{Subgroup analyses}

Subgroup analyses were conducted to examine the stability of the primary results (table 3 ). The associations between egg consumption and risk of coronary heart disease and stroke were similar in subgroup analyses, which were defined by sex, study location, number of cases or participants, duration of follow-up, repeated egg consumption measurements, study quality, and whether diet variables or cholesterol levels were controlled for in models. An increment of one egg consumed per day did not significantly increase risk of coronary heart disease or stroke in any of the categories.

\section{Discussion}

This meta-analysis identified no significant association between egg consumption and risk of coronary heart disease or stroke. Higher intake of eggs (up to one egg per day) was not associated 
with risk of coronary heart disease or stroke. Similar results were obtained in subgroup analyses. However, among diabetic participants, higher egg consumption was associated with a significantly elevated risk of coronary heart disease. On the other hand, higher egg intake was associated with a lower risk of hemorrhagic stroke. These subgroup results should be interpreted with caution, because only a few studies focused on diabetic participants and particular stroke subtypes.

\section{Results in relation to other studies}

To date, the majority of prospective studies have found no significant association between egg consumption and risk of coronary heart disease or stroke. However, Burke and colleagues $^{43}$ analyzed data from 514 Western Australian aborigines with almost 14 years of follow-up and found that risk of coronary heart disease increased in participants consuming eggs more than twice per week. But this study was small and analyzed multiple dietary and lifestyle exposures.

Some studies have found an inverse association between egg consumption and stroke risk. For example, an analysis of the Third National Health and Nutrition Examination Survey 1988-1994 (NHANES III) dataset found a significant inverse association between higher egg consumption and stroke mortality among men. ${ }^{34} \mathrm{~A}$ cohort study from Japan found that increased consumption of animal products (including eggs) was associated with reduced risk of total and hemorrhagic stroke death. $^{39}$

We considered several potential reasons for the lack of an overall association between egg consumption and coronary heart disease or stroke. Although dietary cholesterol influences plasma concentrations of serum cholesterol, the effects are relatively small. ${ }^{10}$ In addition, epidemiologic studies have found weak or little association between dietary cholesterol intake and cardiovascular disease risk. ${ }^{10}$ Apart from dietary cholesterol, saturated fat and dietary patterns might also influence blood cholesterol levels, ${ }^{44-46}$ suggesting that compliance with general dietary recommendations instead of simply reducing egg consumption could have a greater effect on the risk of cardiovascular disease. Additionally, individual differences in response to dietary cholesterol vary greatly, which could affect the association between egg consumption and risk of coronary heart disease and stroke. Moreover, several studies have shown that egg consumption favors the formation of larger LDL and HDL particles, which might enhance protection against atherosclerosis. ${ }^{47} 48$

Other than cholesterol, eggs are a good source of other nutrients such as high quality protein and vitamin D. In the Diet, Obesity, and Gene (Diogenes) Project, increased protein consumption together with a modest reduction in glycemic index was beneficial for weight control ${ }^{49}$ Substituting protein for carbohydrate also partly resulted in lower blood pressure, improved lipids levels, and concomitantly reduced cardiovascular risk. ${ }^{50}$ Higher vitamin D intake might have beneficial effects on the reduction of visceral adipose tissue ${ }^{51}$ and other cardiovascular risk factors ${ }^{52}$.

Another possibility is that lifestyle factors associated with egg consumption might have obscured a positive association between egg consumption and risk of coronary heart disease and stroke. However, regular egg consumption tends to be associated with unhealthy lifestyle factors such as smoking and physical inactivity. ${ }^{34653}$ Higher consumption of eggs is also likely to be associated with increased consumption of red and processed meats. ${ }^{36}$ These confounding factors tend to exaggerate rather than mask the association between egg consumption and cardiovascular disease risk. One study found that participants with high levels of cholesterol in the blood were more likely to reduce their egg consumption than others. ${ }^{40}$ However, our subgroup analysis showed that the association between egg consumption and coronary heart disease was similar in the models, with or without adjustment for cholesterol levels.

Recently, a cross sectional study assessed the total plaque area in patients attending Canadian vascular prevention clinics to determine whether the atherosclerosis burden was related to dietary egg intake. ${ }^{54}$ The study found a strong positive association between the number of egg yolks and the degree of atherosclerosis measured by plaque areas. However, the study did not assess or adjust for other dietary or lifestyle factors and did not examine hard cardiovascular disease endpoints. The cross sectional nature of the study also limited causal interpretation of the data. Therefore, the results from this cross sectional analysis should be interpreted with caution. ${ }^{55}$ The findings from our meta-analyses of prospective cohort studies do not support a positive association between egg consumption and cardiovascular disease outcomes in the general population.

Subgroup analyses have suggested a positive association between egg consumption and coronary heart disease risk in diabetic patients. Among diabetic populations, decreased plasma levels of apolipoprotein E, together with increased levels of apolipoprotein C-III could lead to abnormal cholesterol transport, which might increase the risk of coronary heart disease. ${ }^{565}$ The adverse effect of egg consumption on lipoprotein profile and glycemic control could contribute to the elevated risk of coronary heart disease in diabetic populations. In addition, insulin sensitivity could influence HDL metabolism and cholesterol transport. ${ }^{58}{ }^{59}$ Riemens and colleagues ${ }^{60}$ found that people with lower insulin sensitivity had increased levels of plasma cholesterol, very low density lipoprotein cholesterol, and LDL cholesterol, compared with those with higher insulin sensitivity. Activities of plasma lecithin, cholesterol acyl transferase, phospholipid transfer protein, and hepatic lipase were negatively correlated with insulin sensitivity, which could have enhanced reverse cholesterol transport. ${ }^{60}$ These findings suggest a biological mechanism for possible adverse effects of insulin resistance on risk of coronary heart disease in diabetic populations through cholesterol metabolism. Nonetheless, this subgroup finding of a positive association between egg consumption and coronary heart disease risk was based on a small number of studies and thus needs to be replicated in further studies.

Several prospective cohort studies showed that hemorrhagic stroke had an inverse association with serum levels of cholesterol. ${ }^{61-64}$ In particular, the result of a meta-analysis including 13 cohorts from China and Japan showed that decreased cholesterol concentrations conferred an increased risk of hemorrhagic stroke. ${ }^{65}$ It has been suggested that low cholesterol levels promote necrosis of medial muscle cells and reduce platelet aggregability, which could lead to plasmatic arterionecrosis and the incidence of hemorrhagic stroke. ${ }^{66}{ }^{67} \mathrm{It}$ is unclear whether the inverse association between egg consumption and hemorrhagic stroke is mediated through low levels of serum cholesterol or other mechanisms. Since this subgroup finding was based on a small number of studies, the results should be interpreted with caution.

\section{Strengths and limitations}

Our study has several strengths. Our meta-analysis included prospective cohort studies with large sample size and long duration of follow-up, which significantly increased the 
statistical power to detect potential associations. We investigated a dose-response relation between egg consumption and risk of coronary heart disease and stroke, allowing us to examine the shape of this possible association. Linear and non-linear relations were also tested to quantify the associations. In addition, we used models adjusting for most established risk factors and did stratified analyses to explore whether some factors could explain the results.

Several limitations of our study should also be acknowledged. Firstly, errors in measurement of egg intake and other dietary habits could have attenuated individual study results and led to the null association between egg consumption and risk of coronary heart disease and stroke. All the studies in our analysis assessed egg consumption using food frequency questionnaires, several of which have been validated with reasonable reproducibility and validity of self reported egg intake. However, misreporting of intake was still inevitable. ${ }^{68-70}$

The cooking methods of eggs and the amount of salt added to eggs were not available in most of the included studies. The nutrient contents of eggs could alter depending on different cooking methods or feeding methods of chicken. In addition, we could not uniformly quantify the size of eggs in each study. Moreover, participants with higher egg intake consumed more dietary cholesterol and protein but fewer carbohydrates and were more likely to have lower levels of education than those with lower egg intake. ${ }^{34}$ Several studies adjusted for those confounding factors. To reduce this bias, we conducted a stratified analysis and found the results to be robust in different strata of covariates.

Secondly, during the long follow-up, participants may have changed their diets. However, in our meta-analysis, nearly half the included studies updated the diet information from food frequency questionnaires. Stratified analysis indicated that the associations between egg consumption and risk of coronary heart disease and stroke were similar, regardless of whether repeated egg consumption measurements were considered.

Thirdly, some studies considered the intake of foods in which egg was the main ingredient. However, the results suggested that the amount of eggs estimated in other foods was relatively small and was unlikely to affect the aforementioned associations. Finally, the statistical power was limited in subgroup analyses of diabetic patients or subtypes of stroke.

\section{Conclusions}

In summary, results from our meta-analysis do not support that higher egg consumption is associated with elevated risk of coronary heart disease and stroke. Subgroup analyses suggest a positive association between higher egg intake and risk of coronary heart disease in diabetic patients, and an inverse association between higher egg consumption and incidence of hemorrhagic stroke. Studies with larger sample sizes and longer follow-up times are warranted to confirm these subgroup results.

We thank Catherine Sauvaget, Eric J Grant, and Adam M Bernstein for providing data for the meta-analysis.

Contributors: YR and LL conceived the study. YR and LC searched the databases and checked them according to the eligible criteria and exclusion criteria. LL helped develop search strategies. TZ gave advice on meta-analysis methodology. YS helped extract quantitative data from some papers. YS, MY, and ZS analyzed the data. YR wrote the draft of the paper. LC, TZ, YS, MY, ZS, AS, FBH, and LL contributed to writing, reviewing, or revising the paper. $L L$ is the guarantor.

Funding: This work was funded by the National Science and Technology Support Program (2012BAI02B02), National Natural Science Foundation
(NSFC 81072291), and National Basic Research Program (2009CB118803) of China. The funders had no role in study design, data collection and analysis, decision to publish, or preparation of the manuscript.

Competing interests: All authors have completed the ICMJE uniform disclosure form at www.icmje.org/coi_disclosure.pdf (available on request from the corresponding author) and declare: no support from any organization for the submitted work; no financial relationships with any organizations that might have an interest in the submitted work in the previous three years; and no other relationships or activities that could appear to have influenced the submitted work.

Ethical approval: Ethical approval not needed.

Data sharing: No additional data available.

1 Ford ES, Capewell S. Coronary heart disease mortality among young adults in the U.S. from 1980 through 2002: concealed leveling of mortality rates. J Am Coll Cardiol 2007;50:2128-32.

2 Roger VL, Go AS, Lloyd-Jones DM, Benjamin EJ, Berry JD, Borden WB, et al. Heart disease and stroke statistics-2012 update: a report from the American Heart Association. Circulation 2012;125:e2-220.

3 Roger VL, Go AS, Lloyd-Jones DM, Benjamin EJ, Berry JD, Borden WB, et al. Executive summary: heart disease and stroke statistics-2012 update: a report from the American Heart Association. Circulation 2012;125:188-97.

4 Celermajer DS, Chow CK, Marijon E, Anstey NM, Woo KS. Cardiovascular disease in the developing world: prevalences, patterns, and the potential of early disease detection. J Am Coll Cardiol 2012;60:1207-16

5 Ridker PM, Rifai N, Rose L, Buring JE, Cook NR. Comparison of C-reactive protein and low-density lipoprotein cholesterol levels in the prediction of first cardiovascular events. N Engl J Med 2002;347:1557-65.

6 Cholesterol Treatment Trialists' (CTT) Collaborators. The effects of lowering LDL cholesterol with statin therapy in people at low risk of vascular disease: meta-analysis of individual data from 27 randomised trials. Lancet 2012;380:581-90.

7 Baigent C, Blackwell L, Emberson J, Holland LE, Reith C, Bhala N, et al. Efficacy and safety of more intensive lowering of LDL cholesterol: a meta-analysis of data from 170,000 participants in 26 randomised trials. Lancet 2010;376:1670-81.

8 Briel M, Ferreira-Gonzalez I, You JJ, Karanicolas PJ, Akl EA, Wu P, et al. Association between change in high density lipoprotein cholesterol and cardiovascular disease morbidity and mortality: systematic review and meta-regression analysis. $B M J$ 2009;338:b92.

9 Sniderman AD, Williams K, Contois JH, Monroe HM, McQueen MJ, de Graaf J, et al. A meta-analysis of low-density lipoprotein cholesterol, non-high-density lipoprotein cholesterol, and apolipoprotein B as markers of cardiovascular risk. Circ Cardiovasc Qual Outcomes 2011;4:337-45.

10 Kanter MM, Kris-Etherton PM, Fernandez ML, Vickers KC, Katz DL. Exploring the factors that affect blood cholesterol and heart disease risk: is dietary cholesterol as bad for you as history leads us to believe? Adv Nutr 2012;3:711-7.

11 Spence JD, Jenkins DJ, Davignon J. Dietary cholesterol and egg yolks: not for patients at risk of vascular disease. Can J Cardiol 2010;26:e336-9.

12 Lichtenstein AH, Appel LJ, Brands M, Carnethon M, Daniels S, Franch HA, et al. Summary of American Heart Association Diet and Lifestyle Recommendations revision 2006. Arterioscler Thromb Vasc Biol 2006;26:2186-91.

13 Lichtenstein AH, Appel LJ, Brands M, Carnethon M, Daniels S, Franch HA, et al. Diet and lifestyle recommendations revision 2006: a scientific statement from the American Heart Association Nutrition Committee. Circulation 2006;114:82-96.

14 Krauss RM, Eckel RH, Howard B, Appel LJ, Daniels SR, Deckelbaum RJ, et al. AHA Dietary Guidelines: revision 2000: a statement for healthcare professionals from the Nutrition Committee of the American Heart Association. Stroke 2000;31:2751-66.

15 Song WO, Kerver JM. Nutritional contribution of eggs to American diets. J Am Coll Nutr 2000;19(5 suppl):556-62S

16 Mutungi G, Ratliff J, Puglisi M, Torres-Gonzalez M, Vaishnav U, Leite JO, et al. Dietary cholesterol from eggs increases plasma HDL cholesterol in overweight men consuming a carbohydrate-restricted diet. J Nutr 2008:138:272-6.

17 Di Angelantonio E, Sarwar N, Perry P, Kaptoge S, Ray KK, Thompson A, et al. Major lipids, apolipoproteins, and risk of vascular disease. JAMA 2009;302:1993-2000.

18 Huxley RR, Barzi F, Lam TH, Czernichow S, Fang X, Welborn T, et al. Isolated low levels of high-density lipoprotein cholesterol are associated with an increased risk of coronary heart disease: an individual participant data meta-analysis of 23 studies in the Asia-Pacific region. Circulation 2011;124:2056-64.

19 Better Health Channel (Australia). Cholesterol. 2009. www.betterhealth.vic.gov.au/Bhcv2/ bhcarticles.nst/pages/Cholesterol_explained?open.

20 Food and Agricultural Organization of the United Nations. Food based dietary guidelines by country. 2009. www.fao.org/ag/humannutrition/nutritioneducation/fbdg/en/.

21 Stroup DF, Berlin JA, Morton SC, Olkin I, Williamson GD, Rennie D, et al. Meta-analysis of observational studies in epidemiology: a proposal for reporting. Meta-analysis $\mathrm{O}$ Observational Studies in Epidemiology (MOOSE) group. JAMA 2000;283:2008-12.

22 Wells GA, Shea B, O'Connell D, Peterson J, Welch V, Losos M, et al. The Newcastle-Ottawa Scale (NOS) for assessing the quality of nonrandomized studies in meta-analyses. 2011. www.ohri.ca/programs/clinical_epidemiology/oxford.asp.

23 Greenland S, Longnecker MP. Methods for trend estimation from summarized dose-response data, with applications to meta-analysis. Am J Epidemiol 1992;135:1301-9.

24 Orsini N, Bellocco R, Greenland S. Generalized least squares for trend estimation of summarized dose-response data. Stata Journal 2006;6:40-57.

25 Harrell FE Jr, Lee KL, Pollock BG. Regression models in clinical studies: determining relationships between predictors and response. J Natl Cancer Inst 1988;80:1198-202.

26 Higgins JP, Thompson SG, Deeks JJ, Altman DG. Measuring inconsistency in meta-analyses. BMJ 2003;327:557-60.

27 Higgins JP. Commentary: heterogeneity in meta-analysis should be expected and appropriately quantified. Int J Epidemiol 2008;37:1158-60. 


\section{What is already known on this topic}

Cardiovascular disease affects millions of people in both developed and developing countries

As a major source of dietary cholesterol, eggs have been investigated by several epidemiologic studies in relation to risk of coronary heart disease and stroke

However, whether egg consumption increases the future risk of coronary heart disease and stroke remains unclear

\section{What this study adds}

Consumption of up to one egg per day was not associated with increased risk of coronary heart disease or stroke

Subgroup analysis suggested that consumption of up to one egg per day was associated with a significantly elevated risk of coronary heart disease in diabetic populations, and a reduced risk of hemorrhagic stroke

28 Lau J, loannidis JP, Schmid CH. Quantitative synthesis in systematic reviews. Ann Intern Med 1997;127:820-6

29 Dawber TR, Nickerson RJ, Brand FN, Pool J. Eggs, serum cholesterol, and coronary heart disease. Am J Clin Nutr 1982;36:617-25.

30 Smith MA, Finn R, Green JR. Egg and meat consumption in myocardial infarction. Practitioner 1983;227:673-4.

31 Houston DK, Ding J, Lee JS, Garcia M, Kanaya AM, Tylavsky FA, et al. Dietary fat and cholesterol and risk of cardiovascular disease in older adults: the Health ABC Study. Nutr Metab Cardiovasc Dis 2011;21:430-7.

32 Zazpe I, Beunza JJ, Bes-Rastrollo M, Warnberg J, de la Fuente-Arrillaga C, Benito S, et al. Egg consumption and risk of cardiovascular disease in the SUN Project. Eur J Clin Nutr 2011;65:676-82.

33 Scrafford C, Tran N, Barraj L. The impact of egg consumption on heart health using the NHANES III follow-up survey. FASEB J 2009;23(S1).

34 Scrafford CG, Tran NL, Barraj LM, Mink PJ. Egg consumption and CHD and stroke mortality: a prospective study of US adults. Public Health Nutr 2011;14:261-70.

35 He K, Merchant A, Rimm EB, Rosner BA, Stampfer MJ, Willett WC, et al. Dietary fat intake and risk of stroke in male US healthcare professionals: 14 year prospective cohort study. BMJ 2003;327:777-82.

36 Hu FB, Stampfer MJ, Rimm EB, Manson JE, Ascherio A, Colditz GA, et al. A prospective study of egg consumption and risk of cardiovascular disease in men and women. JAMA 1999;281:1387-94

37 Nakamura Y, Okamura T, Tamaki S, Kadowaki T, Hayakawa T, Kita Y, et al. Egg consumption, serum cholesterol, and cause-specific and all-cause mortality: the National Integrated Project for Prospective Observation of Non-communicable Disease and lts Trends in the Aged, 1980 (NIPPON DATA80). Am J Clin Nutr 2004;80:58-63.

38 Bernstein AM, Pan A, Rexrode KM, Stampfer M, Hu FB, Mozaffarian D, et al. Dietary protein sources and the risk of stroke in men and women. Stroke 2012;43:637-44.

39 Sauvaget C, Nagano J, Allen N, Grant EJ, Beral V. Intake of animal products and stroke mortality in the Hiroshima/Nagasaki Life Span Study. Int J Epidemiol 2003;32:536-43.

40 Nakamura $\mathrm{Y}$, Iso H, Kita Y, Ueshima H, Okada K, Konishi M, et al. Egg consumption, serum total cholesterol concentrations and coronary heart disease incidence: Japan Public Health Center-based prospective study. Br J Nutr 2006;96:921-8.

41 Qureshi Al, Suri FK, Ahmed S, Nasar A, Divani AA, Kirmani JF. Regular egg consumption does not increase the risk of stroke and cardiovascular diseases. Med Sci Monit 2007;13:CR1-8.

42 Djousse L, Gaziano JM. Egg consumption in relation to cardiovascular disease and mortality: the Physicians' Health Study. Am J Clin Nutr 2008:87:964-9.

43 Burke V, Zhao Y, Lee AH, Hunter E, Spargo RM, Gracey M, et al. Health-related behaviours as predictors of mortality and morbidity in Australian Aborigines. Prev Med 2007;44:135-42

44 Spady DK, Woollett LA, Dietschy JM. Regulation of plasma LDL-cholesterol levels by dietary cholesterol and fatty acids. Annu Rev Nutr 1993;13:355-81.

45 Clarke R, Frost C, Collins R, Appleby P, Peto R. Dietary lipids and blood cholesterol: quantitative meta-analysis of metabolic ward studies. BMJ 1997;314:112-7.

46 Howell WH, McNamara DJ, Tosca MA, Smith BT, Gaines JA. Plasma lipid and lipoprotein responses to dietary fat and cholesterol: a meta-analysis. Am J Clin Nutr 1997;65:1747-64

47 Greene CM, Waters D, Clark RM, Contois JH, Fernandez ML. Plasma LDL and HDL characteristics and carotenoid content are positively influenced by egg consumption in an elderly population. Nutr Metab (Lond) 2006:3:6.

48 Mutungi G, Waters D, Ratliff J, Puglisi M, Clark RM, Volek JS, et al. Eggs distinctly modulate plasma carotenoid and lipoprotein subclasses in adult men following a carbohydrate-restricted diet. J Nutr Biochem 2010;21:261-7.

49 Larsen TM, Dalskov SM, van Baak M, Jebb SA, Papadaki A, Pfeiffer AF, et al. Diets with high or low protein content and glycemic index for weight-loss maintenance. $N$ Engl $J$ Med 2010;363:2102-13

50 Appel LJ, Sacks FM, Carey VJ, Obarzanek E, Swain JF, Miller ER 3rd, et al. Effects of protein, monounsaturated fat, and carbohydrate intake on blood pressure and serum lipids: results of the OmniHeart randomized trial. JAMA 2005;294:2455-64.

51 Rosenblum JL, Castro VM, Moore CE, Kaplan LM. Calcium and vitamin D supplementation is associated with decreased abdominal visceral adipose tissue in overweight and obese adults. Am J Clin Nutr 2012;95:101-8.
52 Brandenburg VM, Vervloet MG, Marx N. The role of vitamin D in cardiovascular disease: from present evidence to future perspectives. Atherosclerosis 2012;225:253-63.

53 Djousse L, Gaziano JM. Egg consumption and risk of heart failure in the Physicians' Health Study. Circulation 2008;117:512-6.

54 Spence JD, Jenkins DJ, Davignon J. Egg yolk consumption and carotid plaque. Atherosclerosis 2012;224:469-73.

55 Zampelas A. Still questioning the association between egg consumption and the risk of cardiovascular diseases. Atherosclerosis 2012;224:318-9.

56 Fielding CJ, Castro GR, Donner C, Fielding PE, Reaven GM. Distribution of apolipoprotein $E$ in the plasma of insulin-dependent and noninsulin-dependent diabetics and its relation to cholesterol net transport. J Lipid Res 1986;27:1052-61.

57 Venkatesan S, Imrie H, Read S, Halliday D. Apo C subclasses from non-insulin-dependent diabetic patients-a quantitative comparison with control subjects. Biochem Soc Trans 1995;23:278S.

58 Howard BV. Insulin resistance and lipid metabolism. Am J Cardiol 1999;84:28-32J.

59 Borggreve SE, De Vries R, Dullaart RP. Alterations in high-density lipoprotein metabolism and reverse cholesterol transport in insulin resistance and type 2 diabetes mellitus: role of lipolytic enzymes, lecithin:cholesterol acyltransferase and lipid transfer proteins. Eur Clin Invest 2003;33:1051-69.

60 Riemens SC, Van Tol A, Stulp BK, Dullaart RP. Influence of insulin sensitivity and the TaqIB cholesteryl ester transfer protein gene polymorphism on plasma lecithin:cholesterol acyltransferase and lipid transfer protein activities and their response to hyperinsulinemia in non-diabetic men. $J$ Lipid Res 1999;40:1467-74.

61 Tanaka H, Ueda Y, Hayashi M, Date C, Baba T, Yamashita H, et al. Risk factors for cerebral hemorrhage and cerebral infarction in a Japanese rural community. Stroke 1982;13:62-73.

62 Iso H, Jacobs DR Jr, Wentworth D, Neaton JD, Cohen JD. Serum cholesterol levels and six-year mortality from stroke in 350,977 men screened for the multiple risk factor intervention trial. N Engl J Med 1989;320:904-10

63 Yano K, Reed DM, MacLean CJ. Serum cholesterol and hemorrhagic stroke in the Honolulu Heart Program. Stroke 1989;20:1460-5.

64 Neaton JD, Blackburn H, Jacobs D, Kuller L, Lee DJ, Sherwin R, et al. Serum cholestero level and mortality findings for men screened in the Multiple Risk Factor Intervention Trial. Multiple Risk Factor Intervention Trial Research Group. Arch Intern Med 1992;152:1490-500.

65 Blood pressure, cholesterol, and stroke in eastern Asia. Eastern Stroke and Coronary Heart Disease Collaborative Research Group. Lancet 1998;352:1801-7.

66 Ooneda G, Yoshida Y, Suzuki K, Shinkai H, Hori S, Kobori K, et al. Smooth muscle cells in the development of plasmatic arterionecrosis, arteriosclerosis, and arterial contraction. Blood Vessels 1978;15:148-56.

67 Tandon N, Harmon JT, Rodbard D, Jamieson GA. Thrombin receptors define responsiveness of cholesterol-modified platelets. J Biol Chem 1983;258:11840-5.

68 Westerterp KR, Goris AH. Validity of the assessment of dietary intake: problems of misreporting. Curr Opin Clin Nutr Metab Care 2002;5:489-93.

69 Bingham SA, Luben R, Welch A, Wareham N, Khaw KT, Day N. Are imprecise methods obscuring a relation between fat and breast cancer? Lancet 2003;362:212-4.

70 Kipnis V, Freedman LS. Impact of exposure measurement error in nutritional epidemiology. J Natl Cancer Inst 2008;100:1658-9.

Accepted: 10 December 2012

\section{Cite this as: BMJ 2013:346:e8539}

This is an open-access article distributed under the terms of the Creative Commons Attribution Non-commercial License, which permits use, distribution, and reproduction in any medium, provided the original work is properly cited, the use is non commercial and is otherwise in compliance with the license. See: http://creativecommons.org/licenses/bync/2.0/ and http://creativecommons.org/licenses/by-nc/2.0/legalcode. 


\section{Tables}

Table 1/ Characteristics of participants and follow-up in included studies of egg consumption in relation to risk of coronary heart disease and stroke

\begin{tabular}{|c|c|c|c|c|c|c|c|c|}
\hline Author & $\begin{array}{l}\text { Publication } \\
\text { year }\end{array}$ & Study name & Country & $\begin{array}{c}\text { Sex of } \\
\text { population }\end{array}$ & $\begin{array}{c}\text { Age at } \\
\text { baseline } \\
\text { (years) }\end{array}$ & $\begin{array}{l}\text { No of } \\
\text { participants }\end{array}$ & $\begin{array}{l}\text { Mean length } \\
\text { of follow-up } \\
\text { (years) }\end{array}$ & Endpoints (No of cases) \\
\hline Hu et a $\left.\right|^{36}$ & 1999 & $\begin{array}{l}\text { Health Professionals } \\
\text { Follow-up Study }\end{array}$ & USA & Male & $40-75$ & 37851 & 8 & Coronary heart disease (866) \\
\hline Hu et a $\left.\right|^{36}$ & 1999 & Nurses' Health Study & USA & Female & $34-59$ & 80082 & 14 & Coronary heart disease (939) \\
\hline Sauvaget et $\mathrm{al}^{39}$ & 2003 & $\begin{array}{l}\text { Hiroshima/Nagasaki } \\
\text { Life Span Study }\end{array}$ & Japan & $\begin{array}{l}\text { Male and } \\
\text { female }\end{array}$ & $34-103$ & 34807 & $16-17$ & Stroke mortality (1259) \\
\hline Nakamura et a ${ }^{37}$ & 2004 & NIPPON DATA80 & Japan & Male & $30+$ & 4077 & 14 & $\begin{array}{l}\text { Ischemic heart disease } \\
\text { mortality (39), stroke } \\
\text { mortality (112) }\end{array}$ \\
\hline Nakamura et al ${ }^{37}$ & 2004 & NIPPON DATA80 & Japan & Female & $30+$ & 5186 & 14 & $\begin{array}{l}\text { Ischemic heart disease } \\
\text { mortality }(41), \text { stroke } \\
\text { mortality (107) }\end{array}$ \\
\hline Nakamura et al ${ }^{40}$ & 2006 & $\begin{array}{l}\text { Japan Public Health } \\
\text { Center-based } \\
\text { prospective study }\end{array}$ & Japan & $\begin{array}{l}\text { Male and } \\
\text { female }\end{array}$ & $40-69$ & 90735 & 10.2 & Coronary heart disease (462) \\
\hline Qureshi et al ${ }^{41}$ & 2007 & NHANES-I & USA & $\begin{array}{l}\text { Male and } \\
\text { female }\end{array}$ & $25-74$ & 9734 & 20 & $\begin{array}{l}\text { Coronary artery disease } \\
\text { (1584), stroke (655) }\end{array}$ \\
\hline Djousse et $\mathrm{al}^{42}$ & 2008 & $\begin{array}{l}\text { Physicians' Health } \\
\text { Study I }\end{array}$ & USA & Male & $40-85$ & 21327 & 20 & $\begin{array}{c}\text { Myocardial infarction (1550), } \\
\text { stroke (1342) }\end{array}$ \\
\hline Scrafford et $\mathrm{al}^{34}$ & 2011 & NHANES III & USA & Male & $17+$ & 6833 & 8.8 & $\begin{array}{l}\text { Coronary heart disease } \\
\text { mortality }(198), \text { stroke } \\
\text { mortality }(63)\end{array}$ \\
\hline Scrafford et a $\left.\right|^{34}$ & 2011 & NHANES III & USA & Female & $17+$ & 8113 & 8.9 & $\begin{array}{c}\text { Coronary heart disease } \\
\text { mortality }(168), \text { stroke } \\
\text { mortality }(74)\end{array}$ \\
\hline Bernstein et $\mathrm{al}^{38}$ & 2012 & $\begin{array}{l}\text { Health Professionals } \\
\text { Follow-Up Study }\end{array}$ & USA & Male & $40-75$ & 43150 & 22 & Stroke (1397) \\
\hline Bernstein et $\mathrm{al}^{38}$ & 2012 & Nurses' Health Study & USA & Female & $30-55$ & 84010 & 26 & Stroke (2633) \\
\hline
\end{tabular}

NHANES-I=First National Health and Nutrition Examination Survey; NHANES III=Third National Health and Nutrition Examination Survey; NIPPON DATA80=National Integrated Project for Prospective Observation of Non-communicable Disease and its Trends in the Aged, 1980. 


\begin{tabular}{|c|c|c|c|}
\hline Study & Endpoints & Case ascertainment & Dietary category and relative risk $(95 \% \mathrm{Cl})$ \\
\hline $\begin{array}{l}\text { Hu et al, } 1999^{36} \\
\text { (men) }\end{array}$ & $\begin{array}{l}\text { Coronary heart } \\
\text { disease }\end{array}$ & $\begin{array}{l}\text { Self reported diagnosis } \\
\text { or confirmed by medical } \\
\text { records or autopsy }\end{array}$ & $\begin{array}{l}<1 \mathrm{egg} / \text { week, } 1.0 \text { (reference); } 1,1.06 \text { (0.88 to } 1.27) \text {; } \\
2-4,1.12(0.95 \text { to } 1.33) ; 5-6,0.90 \text { (0.63 to } 1.27) ; \geq 7 \\
1.08(0.79 \text { to } 1.48)\end{array}$ \\
\hline $\begin{array}{l}\text { Hu et al, } 1999^{36} \\
\text { (women) }\end{array}$ & $\begin{array}{l}\text { Coronary heart } \\
\text { disease }\end{array}$ & Same as above & $\begin{array}{l}<1 \mathrm{egg} / \text { week, } 1.0 \text { (reference); } 1,0.82(0.67 \text { to } 1.00) \\
2-4,0.99(0.82 \text { to } 1.18) ; 5-6,0.95 \text { (0.70 to } 1.29) ; \geq 7 \\
0.82(0.60 \text { to } 1.13)\end{array}$ \\
\hline
\end{tabular}

heart disease and stroke

Covariates in fully adjusted model

\begin{tabular}{llll}
\hline Sauvaget et al, & Stroke mortality & Confirmed by & Never, 1.0 (reference); $\leq 1$ egg/week ${ }^{\star}, 0.74(0.55$ to \\
$2003^{39}$ & nationwide family & $1.00) ; 2-4$ eggs/week, 0.78 (0.59 to 1.04$) ;$ almost daily, \\
& registration system & $0.72(0.54$ to 0.97$)$
\end{tabular}

Age, body mass index, two year time periods, smoking, parental history of myocardial infarction, multivitamin supplement use, alcohol consumption, menopausal status and postmenopausal hormone use (women), history of hypertension, physical activity, and total energy intake Age, sex, birth cohort, city, radiation

Nakamura et al, Ischemic heart Confirmed by National Ischemic heart disease mortality: seldom, $1.18(0.26$
$2004^{37}$ (men) disease mortality, Vital Statistics $\quad$ to 5.42$) ; 1$-2 eggs/week, 1.71 (0.78 to 3.76$) ; 0.5$ stroke mortality $\quad$ eggs/day, 1.49 (0.63 to 3.48$) ; 1$ egg/day, 1.0 (reference) Stroke mortality: seldom, 0.93 (0.36 to 2.40 ); 1 -2 dose, body mass index, smoking, alcohol habits, education level, history of diabetes, or hypertension eggs/week, 1.09 (0.69 to 1.72); 0.5 eggs/day, 1.10 (0.68 to 1.76$) ; 1$ egg/day, 1.0 (reference); $\geq 2$ eggs/day, 0.25 (0.03 to 1.81 )

\begin{tabular}{|c|c|c|c|}
\hline \multirow[t]{2}{*}{$\begin{array}{l}\text { Nakamura et al, } \\
2004^{37} \text { (women) }\end{array}$} & $\begin{array}{l}\text { Ischemic heart } \\
\text { disease mortality, } \\
\text { stroke mortality }\end{array}$ & Same as above & $\begin{array}{l}\text { Ischemic heart disease mortality: seldom, } 1.42(0.56 \\
\text { to } 3.62) ; 1-2 \text { eggs/week, } 0.64(0.28 \text { to } 1.44) ; 0.5 \\
\text { eggs/day, } 0.78 \text { ( } 0.35 \text { to } 1.82) ; 1 \text { egg/day, } 1.0 \\
\text { (reference); } \geq 2 \text { eggs/day, } 1.27 \text { ( } 0.16 \text { to } 9.80)\end{array}$ \\
\hline & & & $\begin{array}{l}\text { Stroke mortality: seldom, } 0.78 \text { ( } 0.35 \text { to } 1.73) ; 1-2 \\
\text { eggs/week, } 0.79 \text { ( } 0.47 \text { to } 1.33) ; 0.5 \text { eggs/day, } 1.46 \\
(0.89 \text { to } 2.4) ; 1 \text { egg/day, } 1.0 \text { (reference); } \geq 2 \text { eggs/day, } \\
1.22 \text { ( } 0.29 \text { to } 5.17)\end{array}$ \\
\hline
\end{tabular}

Nakamura et al, Coronary heart $2006^{40}$ disease
Confirmed by medical records, letter, telephone or death certificate
Age, serum creatinine, total cholesterol, blood glucose, body mass index, blood pressures, use of blood pressure lowering drugs, smoking, and alcohol intake

\begin{tabular}{|c|c|c|c|c|}
\hline $\begin{array}{l}\text { Qureshi et al, } \\
2007^{41}\end{array}$ & $\begin{array}{l}\text { Coronary artery } \\
\text { disease, stroke }\end{array}$ & $\begin{array}{l}\text { Confirmed by medical } \\
\text { records or death } \\
\text { certificate }\end{array}$ & $\begin{array}{l}\text { Coronary artery disease: }<1 \text { egg/week, } 1.0 \text { (reference); } \\
1-6,1.0(0.9 \text { to } 1.1) ;>6,1.1 \text { (0.9 to } 1.3) \\
\text { Stroke: }<1 \text { egg/week, } 1.0 \text { (reference); } 1-6,0.9(0.7 \text { to } \\
1.0) ;>6,0.9(0.7 \text { to } 1.1)\end{array}$ & $\begin{array}{l}\text { Age, sex, race or ethnicity, systolic blood } \\
\text { pressure, diabetes mellitus, serum } \\
\text { cholesterol, smoking, body mass index, } \\
\text { and educational status }\end{array}$ \\
\hline $\begin{array}{l}\text { Djousse et al, } \\
2008^{42}\end{array}$ & $\begin{array}{l}\text { Myocardial infarction, } \\
\text { stroke }\end{array}$ & $\begin{array}{l}\text { Confirmed by } \\
\text { physicians or medical } \\
\text { records }\end{array}$ & $\begin{array}{l}\text { Myocardial infarction: }<1 \text { egg/week, } 1.0 \text { (reference); } \\
1,1.12(0.96 \text { to } 1.31) ; 2-4,1.16(1.00 \text { to } 1.36) ; 5-6 \text {, } \\
1.18(0.93 \text { to } 1.49) ; \geq 7,0.90(0.72 \text { to } 1.14) \\
\text { Stroke: }<1 \text { egg/week, } 1.0 \text { (reference); } 1,0.96(0.82 \text { to } \\
1.13) ; 2-4,1.06(0.91 \text { to } 1.24) ; 5-6,1.13(0.89 \text { to } 1.42) \\
\geq 7,0.99(0.80 \text { to } 1.23)\end{array}$ & $\begin{array}{l}\text { Age, body mass index, smoking, history } \\
\text { of hypertension, vitamin intake, alcohol } \\
\text { consumption, vegetable consumption, } \\
\text { breakfast cereal, physical activity, } \\
\text { treatment arm, atrial fibrillation, diabetes } \\
\text { mellitus, hypercholesterolemia, and } \\
\text { parental history of premature myocardial } \\
\text { infarction }\end{array}$ \\
\hline $\begin{array}{l}\text { Scrafford et al, } \\
2011^{34} \text { (men) }\end{array}$ & $\begin{array}{l}\text { Coronary heart } \\
\text { disease mortality, } \\
\text { stroke mortality }\end{array}$ & Not applicable & $\begin{array}{l}\text { Coronary heart disease mortality: }<1 \text { egg/week, } 1.0 \\
\text { (reference); } 1-6,1.26(0.79 \text { to } 2.00) ;>6,1.13(0.61 \text { to } \\
2.11) \\
\text { Stroke mortality: }<1 \text { egg/week, } 1.0 \text { (reference); } 1-6 \text {, } \\
1.00 \text { ( } 0.49 \text { to } 2.02) ;>6,0.27 \text { ( } 0.10 \text { to } 0.73)\end{array}$ & $\begin{array}{l}\text { Age, energy, marital status, educational } \\
\text { status, race or ethnicity, smoking, body } \\
\text { mass index, waist to hip ratio, diabetes, } \\
\text { hypertension, and dietary variables }\end{array}$ \\
\hline $\begin{array}{l}\text { Scrafford et al, } \\
2011^{34} \text { (women) }\end{array}$ & $\begin{array}{l}\text { Coronary heart } \\
\text { disease mortality, } \\
\text { stroke mortality }\end{array}$ & Not applicable & $\begin{array}{l}\text { Coronary heart disease mortality: }<1 \text { egg/week, } 1.0 \\
\text { (reference); } 1-6,1.12 \text { (0.66 to } 1.89) ;>6,0.92(0.27 \text { to } \\
3.11) \\
\text { Stroke mortality: }<1 \text { egg/week, } 1.0 \text { (reference); } 1-6 \text {, } \\
0.93 \text { (0.46 to } 1.90) ;>6,1.03 \text { ( } 0.25 \text { to } 4.22)\end{array}$ & \\
\hline $\begin{array}{l}\text { Bernstein et al, } \\
2012^{38} \text { (men) }\end{array}$ & Stroke & $\begin{array}{l}\text { Confirmed by medical } \\
\text { records or autopsy } \\
\text { report }\end{array}$ & $\begin{array}{l}0.14 \text { eggs/week†, } 1.0 \text { (reference); } 0.49,0.80 \text { ( } 0.66 \text { to } \\
0.97) ; 1.19,0.88(0.73 \text { to } 1.05) ; 3.01,0.80 \text { ( } 0.66 \text { to } \\
0.96) ; 5.53,0.84 \text { ( } 0.68 \text { to } 1.04)\end{array}$ & $\begin{array}{l}\text { Age, time period, body mass index, } \\
\text { smoking, physical exercise, parental } \\
\text { history of early myocardial infarction, }\end{array}$ \\
\hline $\begin{array}{l}\text { Bernstein et al, } \\
2012^{38} \text { (women) }\end{array}$ & Stroke & Same as above & $\begin{array}{l}0.49 \text { eggs/week } \uparrow, 1.0 \text { (reference); } 1.26,0.90(0.80 \text { to } \\
1.01) ; 2.17,0.94 \text { ( } 0.83 \text { to } 1.05) ; 3.01,0.86(0.76 \text { to } \\
0.99) ; 4.69,0.91 \text { ( } 0.80 \text { to } 1.04)\end{array}$ & $\begin{array}{l}\text { menopausal status in women, } \\
\text { multivitamin use, vitamin E supplement } \\
\text { use, aspirin use at least once per week, } \\
\text { total energy, cereal fiber, alcohol, trans } \\
\text { fat, fruit and vegetables, and other } \\
\text { protein sources }\end{array}$ \\
\hline
\end{tabular}




\section{Table 2 (continued)}

*Unit of egg consumption was assumed.

†Servings per day converted to eggs consumed per week. 


\begin{tabular}{|c|c|c|c|c|c|}
\hline & No of reports ${ }^{*}$ & Relative risk $(95 \% \mathrm{Cl})$ & P for heterogeneity & $I^{2}$ & P for test \\
\hline \multicolumn{6}{|l|}{ Coronary heart disease } \\
\hline Total cases & 9 & $0.99(0.85$ to 1.15$)$ & 0.97 & 0.0 & 0.88 \\
\hline Fatal cases & 4 & $1.18(0.71$ to 1.96$)$ & 0.91 & 0.0 & 0.53 \\
\hline $\begin{array}{l}\text { Coronary heart disease with } \\
\text { diabetest }\end{array}$ & 5 & 1.54 (1.14 to 2.09$)$ & 0.59 & 0.0 & 0.01 \\
\hline \multicolumn{6}{|c|}{ Subgroup analyses for total coronary heart disease } \\
\hline \multicolumn{6}{|l|}{ Sex } \\
\hline Male & 4 & $1.06(0.89$ to 1.25$)$ & 0.83 & 0.0 & 0.53 \\
\hline Female & 3 & $0.99(0.83$ to 1.20$)$ & 0.99 & 0.0 & 0.95 \\
\hline \multicolumn{6}{|l|}{ Study location } \\
\hline USA & 6 & $1.01(0.90$ to 1.13$)$ & 0.96 & 0.0 & 0.89 \\
\hline Asia & 3 & $0.95(0.64$ to 1.41$)$ & 0.76 & 0.0 & 0.79 \\
\hline \multicolumn{6}{|l|}{ No of participants } \\
\hline$>10000$ & 4 & $0.97(0.81$ to 1.15$)$ & 0.87 & 0.0 & 0.70 \\
\hline$\leq 10000$ & 5 & $1.14(0.83$ to 1.56$)$ & 0.93 & 0.0 & 0.42 \\
\hline \multicolumn{6}{|l|}{ No of cases } \\
\hline$>500$ & 4 & $1.00(0.89$ to 1.13$)$ & 0.79 & 0.0 & 0.94 \\
\hline$\leq 500$ & 5 & $0.96(0.67$ to 1.37$)$ & 0.93 & 0.0 & 0.83 \\
\hline \multicolumn{6}{|l|}{ Duration of follow-up } \\
\hline$>15$ years & 2 & $1.02(0.89$ to 1.16$)$ & 0.40 & 0.0 & 0.83 \\
\hline$\leq 15$ years & 7 & $0.98(0.81$ to 1.19$)$ & 0.98 & 0.0 & 0.85 \\
\hline \multicolumn{6}{|c|}{ Repeated egg consumption measurements } \\
\hline Yes & 4 & $0.97(0.81$ to 1.15$)$ & 0.87 & 0.0 & 0.70 \\
\hline No & 5 & $1.14(0.83$ to 1.56$)$ & 0.93 & 0.0 & 0.42 \\
\hline \multicolumn{6}{|l|}{ Study quality } \\
\hline Score $\geq 8$ & 5 & $0.97(0.80$ to 1.17$)$ & 0.93 & 0.0 & 0.74 \\
\hline Score $<8$ & 4 & $1.06(0.88$ to 1.28$)$ & 0.81 & 0.0 & 0.55 \\
\hline \multicolumn{6}{|c|}{ Controlling for other diet variables in models $\ddagger$} \\
\hline Yes & 6 & $0.97(0.82$ to 1.15$)$ & 0.97 & 0.0 & 0.73 \\
\hline No & 5 & $1.14(0.84$ to 1.55$)$ & 0.92 & 0.0 & 0.40 \\
\hline \multicolumn{6}{|c|}{ Controlling for serum cholesterol levels or use of cholesterol lowering drugs in models } \\
\hline Yes & 5 & $0.97(0.75$ to 1.26$)$ & 0.65 & 0.0 & 0.83 \\
\hline No & 4 & $1.01(0.86$ to 1.18$)$ & 0.97 & 0.0 & 0.94 \\
\hline \multicolumn{6}{|l|}{ Stroke } \\
\hline Total stroke & 8 & 0.91 (0.81 to 1.02$)$ & 0.46 & 0.0 & 0.10 \\
\hline Fatal stroke & 4 & $0.94(0.81$ to 1.10$)$ & 0.47 & 0.0 & 0.46 \\
\hline Hemorrhagic stroke $\dagger$ & 3 & 0.75 (0.57 to 0.99$)$ & 0.21 & 36.8 & 0.04 \\
\hline Ischemic stroke $†$ & 4 & $0.91(0.82$ to 1.01$)$ & 0.79 & 0.0 & 0.08 \\
\hline Stroke with diabetes $\dagger$ & 3 & $0.80(0.29$ to 2.15$)$ & 0.09 & 58.9 & 0.65 \\
\hline \multicolumn{6}{|c|}{ Subgroup analyses for total stroke } \\
\hline \multicolumn{6}{|l|}{ Sex } \\
\hline Male & 4 & $0.89(0.77$ to 1.03$)$ & $<0.001$ & 90.5 & 0.13 \\
\hline Female & 4 & 0.91 (0.77 to 1.07$)$ & 0.24 & 29.0 & 0.25 \\
\hline \multicolumn{6}{|l|}{ Study location } \\
\hline USA & 5 & $0.90(0.79$ to 1.03$)$ & 0.38 & 4.9 & 0.13 \\
\hline Asia & 3 & $0.94(0.83$ to 1.07$)$ & 0.28 & 20.6 & 0.34 \\
\hline \multicolumn{6}{|l|}{ No of participants } \\
\hline$>10000$ & 4 & $0.90(0.80$ to 1.02$)$ & 0.25 & 26.9 & 0.10 \\
\hline$\leq 10000$ & 4 & $0.97(0.75$ to 1.27$)$ & 0.50 & 0.0 & 0.85 \\
\hline
\end{tabular}


Table 3 (continued)

\begin{tabular}{|c|c|c|c|c|c|}
\hline & No of reports* & Relative risk $(95 \% \mathrm{Cl})$ & P for heterogeneity & $I^{2}$ & P for test \\
\hline \multicolumn{6}{|l|}{ No of cases } \\
\hline$>500$ & 5 & 0.91 (0.81 to 1.02$)$ & 0.38 & 5.0 & 0.09 \\
\hline$\leq 500$ & 3 & $1.00(0.63$ to 1.59$)$ & 0.35 & 4.2 & 0.99 \\
\hline \multicolumn{6}{|c|}{ Duration of follow-up } \\
\hline$>15$ years & 5 & 0.91 (0.81 to 1.02$)$ & 0.38 & 5.0 & 0.09 \\
\hline$\leq 15$ years & 3 & $1.00(0.63$ to 1.59$)$ & 0.35 & 4.2 & 0.99 \\
\hline \multicolumn{6}{|c|}{ Repeated egg consumption measurements } \\
\hline Yes & 3 & $0.90(0.78$ to 1.04$)$ & 0.13 & 51.5 & 0.14 \\
\hline No & 5 & $0.94(0.83$ to 1.08$)$ & 0.64 & 0.0 & 0.38 \\
\hline \multicolumn{6}{|l|}{ Study quality } \\
\hline Score $\geq 7.5$ & 5 & $1.03(0.88$ to 1.20$)$ & 0.51 & 0.0 & 0.71 \\
\hline Score $<7.5$ & 3 & 0.88 (0.77 to 1.01$)$ & 0.82 & 0.0 & 0.07 \\
\hline \multicolumn{6}{|c|}{ Controlling for other diet variables in models $\ddagger$} \\
\hline Yes & 4 & $0.90(0.79$ to 1.04$)$ & 0.25 & 26.6 & 0.14 \\
\hline No & 5 & 0.95 (0.83 to 1.08$)$ & 0.62 & 0.0 & 0.43 \\
\hline \multicolumn{6}{|c|}{ Controlling for serum cholesterol levels or use of cholesterol lowering drugs in models } \\
\hline Yes & 4 & $1.04(0.91$ to 1.18$)$ & 0.34 & 10.0 & 0.60 \\
\hline No & 4 & 0.89 (0.77 to 1.01$)$ & 0.94 & 0.0 & 0.07 \\
\hline
\end{tabular}

${ }^{*}$ Five articles reported their results by sex group; therefore, there were nine reports from six articles for coronary heart disease and eight reports from six articles for stroke.

†Owing to a lack of data for person years, results are relative risks ( $95 \%$ confidence intervals) comparing highest with lowest egg consumption. $\ddagger$ Study by Scrafford and colleagues reported results both controlling for diet variables and not. 


\section{Figures}

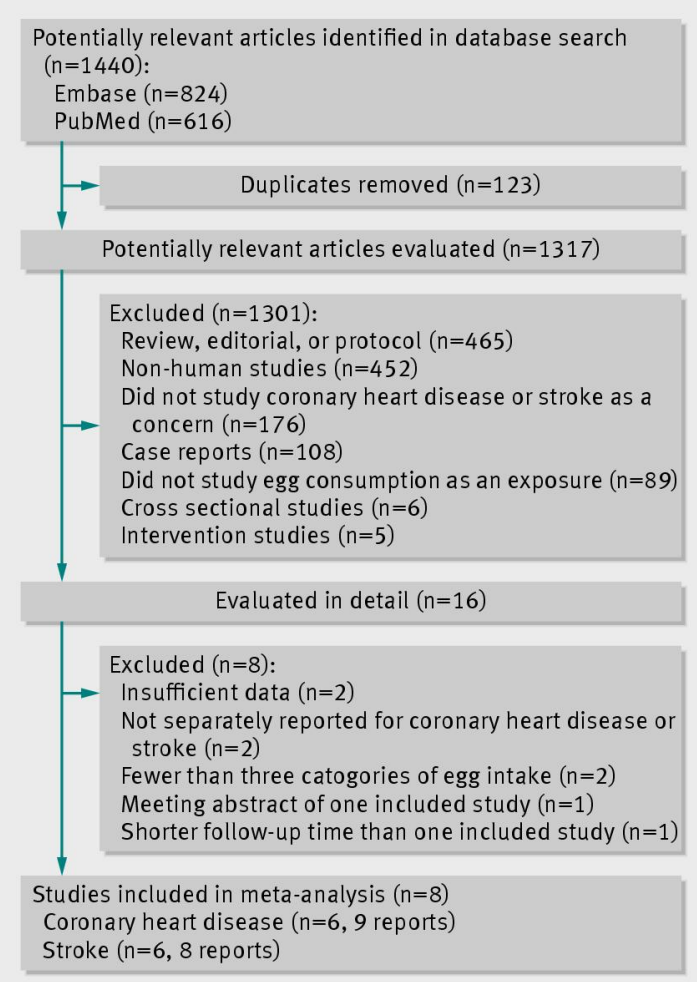

Fig 1 Flow diagram of literature search and study selection

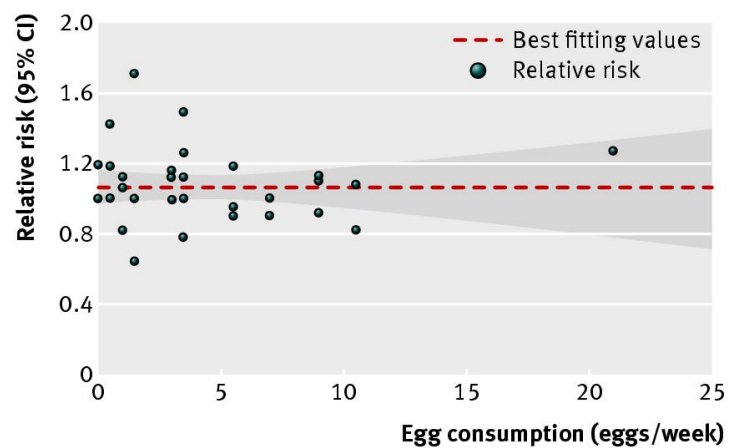

Fig 2 Dose-response analyses of egg consumption and risk of coronary heart disease 


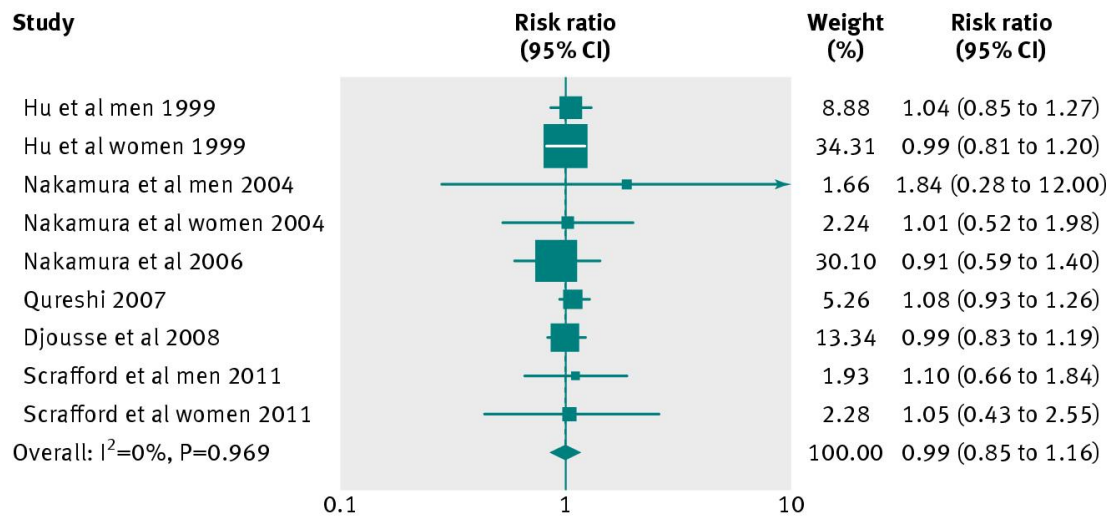

Fig 3 Forest plot of egg consumption and risk of coronary heart disease

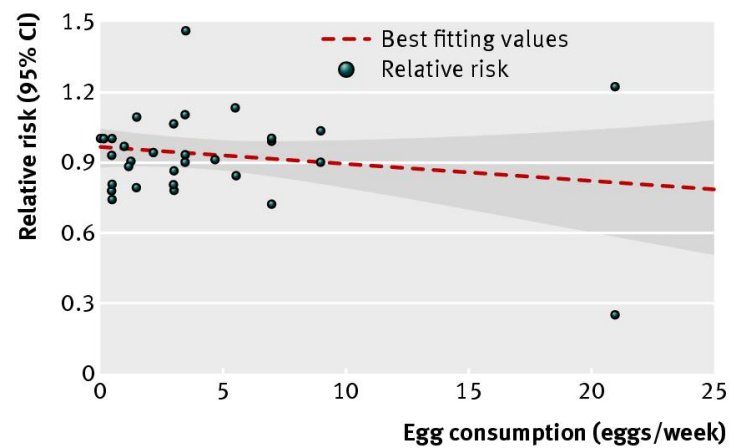

Fig 4 Dose-response analyses of egg consumption and risk of stroke

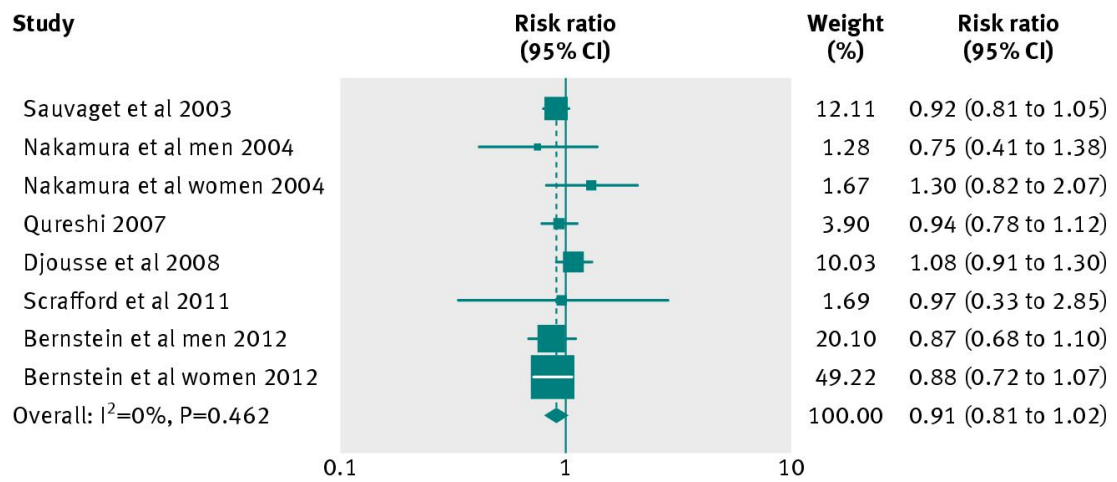

Fig 5 Forest plot of egg consumption and risk of stroke 